\title{
PENGARUH PENGANGGURAN DAN INFLASI TERHADAP PRODUK DOMESTIK BRUTO INDONESIA TAHUN 2009-2019
}

\author{
Sri Harjunawati ${ }^{1}$, Ida Hendarsih ${ }^{2}$ \\ Universitas Bina Sarana Informatika Jakarta \\ sri.shw@bsi.ac.id
}

\begin{abstract}
Abstrak: Sesuai dengan pasal 33 UUD 1945, tujuan utama pemerintah Indonesia adalah kemakmuran rakyat Indonesia. Negara dikatakan makmur jika sebagian besar kebutuhan rakyatnya terpenuhi. Alat pemuas kebutuhan berupa barang dan jasa yang dihasilkan di wilayah Indonesi yaitu Pendapatan Domestik Bruto. Terdapat banyak faktor agregatif ayang berpengaruh terhadap Produk domestik Bruto, diantaranya Pengangguran dan Inflasi. Penelitian ini meneliti pengaruh pengangguran dan inflasi terhadap Produk Domestik Bruto. Penelitian pada pebngaruh variabel bebas Pengangguran (X1) terhadap Produk Domestik Bruto $(\mathrm{Y})$ menghasilkan nilai $\mathrm{t}$ hitung sebesar $-4.974>2.300$ ( $\mathrm{t}$ tabel). Penelitian pada pengaruh variabel bebas Inflasi (X2) terhadap variabel terikat Produk Domestik Bruto menghasilkan nilai $\mathrm{t}$ hitung sebesar $-1.511<2.300$ ( $\mathrm{t}$ tabel). Uji linier berganda pada penelitian ini menghasilkan nilai $\mathrm{F}$ hitung sebesar $14.834>4.35$ (F tabel). Persamaan regresi pada penelitian ini adalah $\mathrm{Y}=21036872.292-1.526 \mathrm{X} 1-127482.199 \mathrm{X} 2+\mathrm{e}$. Nilai $\mathrm{R}$ koefisien korelasi sebesar 0,900 dan nilai $\mathrm{R}$ square 0,809 .
\end{abstract}

Kata Kunci: Pengangguran, Inflasi, Produk Domestik Bruto

\begin{abstract}
In accordance with article 33 of the 1945 Constitution, the main objective of the Indonesian government is the prosperity of the Indonesian people. The state is said to be prosperous if most of the needs of its people are met. Satisfaction needs in the form of goods and services produced in the territory of Indonesia, namely Gross Domestic Revenue. There are many aggregative factors that influence the Gross Domestic Product, including Unemployment and Inflation. This study examines the effect of unemployment and inflation on the Gross Domestic Product. Research on the influence of the Unemployment independent variable (X1) on Gross Domestic Product (Y) produces at-value of -4,974> 2,300 ( $\mathrm{t}$ table). Research on the influence of the Inflation (X2) independent variable on the dependent variable of the Gross Domestic Product yields a calculated value of $-1,511<2,300$ ( $\mathrm{t}$ table). Multiple linear tests in this study produced a calculated $\mathrm{F}$ value of $14,834>4.35$ (F table). The regression equation in this study is $\mathrm{Y}=21036872.292-1.526 \mathrm{X} 1$ 127482.199X2 + e. R-value of the correlation coefficient of 0.900 and $\mathrm{R}$ square value of 0.809 .
\end{abstract}

\section{Keywords: Purchase, Conversation, Gross Domestic Product}

\section{PENDAHULUAN}

Pada pasal 33 UUD 1945 jelas menyiratkan makna bahwa kemakmuran rakyat Indonesia merupakan tujuan utama pemerintah Indonesia, siapapun yang menjalankan roda pemerintahan Indonesia. Secara sederhana, negara dikatakan makmur jika rakyatnya makmur, dalam arti sebagian besar kebutuhannya terpenuhi. 
Untuk memenuhi kebutuhan dibutuhkan alat pemuas kebutuhan, dalam hal ini pendapatan. Secara makro ekonomi, Pendapatan Domestik Bruto dapat digunakan sebagai tolok ukur kemakmuran. Dari pendapatan domestik bruto ini dapat diketahui pendapatan perkapita yang didapat dari Pendapatan Domestik Bruto dibagi jumlah penduduk negara yang bersangkutan.

Pendapatan Domestik Bruto (PDB) adalah jumlah barang dan jasa yang dihasilkan diwilayah suatu negara. Terdapat beberapa faktor yang berpengaruh terhadap PDB, diantaranya inflasi. Laju inflasi berpengaruh terhadap perkembangan sektor usaha, sedangkan sektor usaha sendiri sangat berpengaruh terhadap kegiatan perekonomian dan pada akhirnya berpengaruh terhadap Pendapatan Domestik Bruto negara tersebut.

Inflasi adalah kecenderungan harga umum naik secara terus menerus. Inflasi berkaitan dengan daya beli masyarakat, dalam hal ini daya beli masyarakat tercermin dari nilai uang terhadap barang dan jasa. Nilai uang selalu berbanding terbalik dengan nilai barang dan jasa. Apabila terjadi inflasi berarti terjadi kenaikan harga umum secara terus menerus. Hal ini dapat diartikan sebagai penurunan nilai uang terhadap barang dan jasa. Hukum supply end demand mengatakan bahwa harga akan cenderung meningkat apabila terjadi over supply, dimana jumlah barang dan jasa diminta lebih besar dari pada jumlah barang dan jasa yang tersedia di masyarakat. Jumlah barang dan jasa yang tersedia berkaitan faktor produksi yang dimiliki suatu negara, yaitu faktor sumber daya alam/fisik, faktor sumber daya manusia/tenaga kerja, dan faktor modal. Dalam keadaan cinteris paribus, dimana faktor alam/fisik dan faktor modal dianggap keadaan tetap maka faktor penting yang harus dicermati adalah faktor sumber daya manusia/tenaga kerja.

Presiden Jokowi di awal pemerintahannya telah mencanangkan pembangunan sumber daya manusia sebagai prioritas utama masa pemerintahannya. Disamping peningkatan kemampuan sumber daya manusia, hal yang sampai sekarang masih menjadi polemik perekonomian adalah pengangguran. Kurva philip menyatakan bahwa pengangguran berbanding lurus dengan inflasi. Apabila pengangguran meningkat maka inflasi juga meningkat, sementara inflasi berpengaruh terhadap Produk Domestik Bruto. Penelitian ini akan membahas tentang "Pengaruh Pengangguran dan Inflasi Terhadap Produk Domestik Bruto 
Indonesia Tahun 2009-2019”.

\section{Tinjauan Pustaka}

\section{Pendapatan Domestik Bruto}

Inti dari pengertian Produk Domestik Bruto (PDB) yang dikemukakan oleh Badan Pusat Statistik (BPS) (2019) adalah jumlah nilai barang dan jasa akhir yang dihasilkan oleh seluruh unit ekonomi di wilayah suatu negara. Nilai barang dan jasa yang dimaksudkan disini merupakan nilai tambah yang dihasilkan oleh unit ekonomi yang bersangkutan. Nilai tambah diperoleh dari selisih antara output yang dihasilkan dengan input yang digunakan unit ekonomi tersebut. Output yang dihasilkan merupakan pendapatan yang diperoleh dari hasil penjualan barang atau jasa sedangkan input yang digunakan merupakan pengeluaran atau biaya yang digunakan untuk memperoleh output. Produk domestik bruto sama halnya dengan pendapatan nasional di suatu negara. Menurut Sukirno (2011) dalam bukunya menyatakan bahwa dengan tingkat pendapatan nasional yang tinggi akan mempengaruhi pendapatan masyarakat, selanjutnya pendapatan masyarakat yang tinggi tersebut akan memperbesar permintaan terhadap barang-barang dan jasajasa.

PDB atas dasar harga berlaku merupakan nilai tambah barang dan jasa yang dihitung menggunakan harga yang berlaku pada setiap tahun. PDB atas harga yang berlaku ini digunakan untuk mengetahui pergeseran dan struktur ekonomi. PDB atas dasar harga konstan merupakan nilai tambah barang dan jasa yang dihitung berdasarkan harga yang berlaku pada tahun tertentu sebagai dasar. PDB atas dasar harga konstan ini digunakan untuk mengetahui pertumbuhan ekonomi dari tahun ke tahun. Sesuai dengan fungsinya penelitian ini menggunakan PDB atas dasar harga konstan sehingga dapat mengetahui pertumbuhan ekonomi dari tahun ke tahun.

Angka-angka PDB dapat diperoleh dengan menggunakan tiga pendekatan yaitu pendekatan produksi, pendekatan pendapatan, dan pendekatan pengeluaran. Pendekatan produksi menghitung PDB dengan menjumlahkan nilai tambah barang dan jasa yang dihasilkan berbagai unit produksi di wilayah suatu negara pada satu periode tertentu.

Pendekatan pendapatan menghitung PDB dengan menjumlahkan balas jasa yang diterima oleh faktor-faktor produksi yang ikut serta dalam proses produksi di 
suatu negara pada satu periode tertentu, yaitu upah dan gaji, sewa tanah, bunga modal dan keuntungan. Nilai tersebut dihitung sebelum dipotong pajak penghasilan dan pajak langsung lainnya. Pada pendekatan PDB mencakup juga penyusutan dan pajak tidak langsung neto, yaitu pajak tak langsung dikurangi subsidi.

Pada pendekatan pengeluaran PDB dihitung dengan menjumlahkan semua komponen permintaan akhir, yaitu: pengeluaran konsumsi rumah tangga dan lembaga swasta nirlaba, pengeluaran konsumsi pemerintah, pembentukan modal tetap domestik bruto, perubahan inventori, dan ekspor neto. Ekspor neto merupakan selisih dari ekspor dikurangi impor. Walaupun berbeda, namun ketiga pendekatan tersebut akan menghasilkan angka yang sama. Dengan demikian PDB yang dihasilkan akan sama.

\section{Inflasi}

Menurut BPS (2019),"pengertian inflasi adalah kecenderungan naiknya harga barang dan jasa pada umumnya yang berlangsung secara terus menerus". Inflasi dapat juga diartikan sebagai penurunan nilai uang terhadap nilai barang dan jasa secara umum. Indikator dalam menghitung inflasi adalah Indeks Harga konsumen (IHK). Indeks ini menghitung rata-rata perubahan harga suatu paket barang dan jasa yang dikonsumsi oleh rumah tangga dalam kurun waktu tertentu. Pendapat dari Sukirno (2011) "Inflasi merupakan suatu proses ketika terjadinya suatu kenaikan harga yang berlaku terhadap kegiatan perekonomian”.

Di Indonesia, indikator inflasi, yaitu Indeks Harga Konsumen dihitung dengan rumus Laspeyres termodifikasi dimana ukuran yang digunakan untuk menghitung rata-rata harga komoditas berdasarkan rata-rata aritmatik, tetapi untuk beberapa komoditas seperti beras, minyak goreng, bensin, dan sebagainya digunakan ratarata geometri.

\section{Pengangguran terbuka}

Pengangguran adalah orang yang tidak bekerja. Menurut BPS, pengangguran terbuka adalah orang yang dalam kondisi sebagai berikut:

a. Tidak punya pekerjaan dan mencari pekerjaan.

b. Tidak punya pekerjaan dan mempersiapkan usaha.

c. Tidak punya pekerjaan dan tidak mencari pekerjaan, karena merasa tidak mungkin mendapatkan pekerjaan. 
d. Sudah punya pekerjaan, tetapi belum molai bekerja.

\section{Kerangka Konsep Penelitian dan Hipotesis}

Sesuai dengan judulnya, yaitu pengaruh pengangguran terhadap produk domestik bruto dengan inflasi sebagai intervenning peneliti menyusun kerangka konsep dan hipotesis yang digunakan pada penelitian ini sebagai berikut.

\section{Kerangka konsep penelitian}

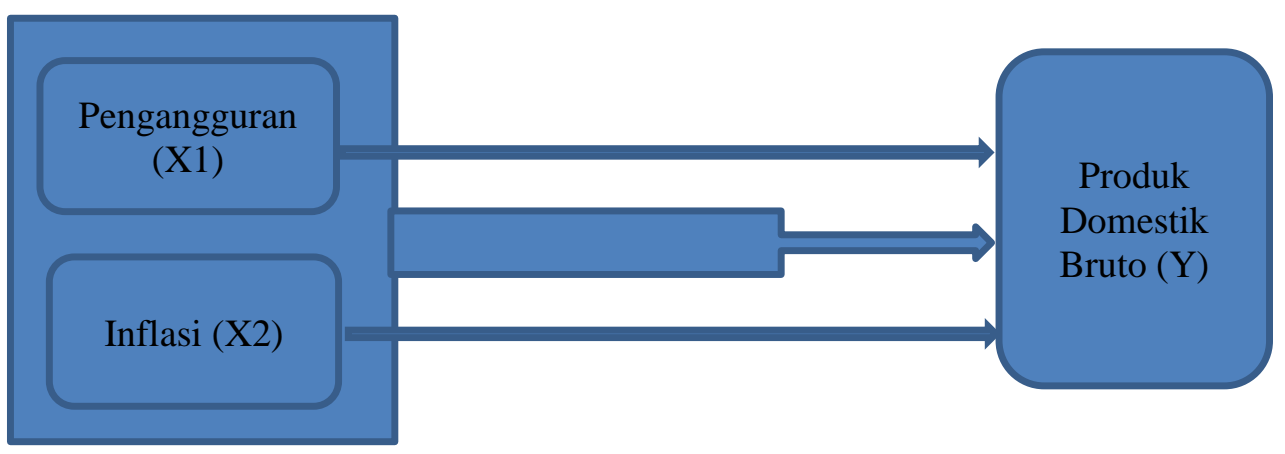

Gambar 1. Kerangka konsep penelitian

\section{Rumusan Masalah/ Hipotesis}

H0a : Tidak terdapat pengaruh pengangguran terhadap Produk Domestik Bruto

H1a : Terdapat pengaruh pengangguran terhadap Produk Domestik Bruto

H0b : Tidak terdapat pengaruh Inflasi terhadap Produk Domestik Bruto

H1b : Terdapat pengaruh Inflasi terhadap Produk Domestik Bruto

H0c : Tidak terdapat pengaruh pengangguran dan inflasi secara bersama-sama terhadap Produk Domestik Bruto

H1c : Terdapat pengaruh pengaruh pengangguran dan inflasi secara bersama-sama terhadap Produk Domestik Bruto

\section{Pembahasan}

Penelitian ini menggunakan data sekunder, yaitu data yang diperoleh dari Badan Pusat Statistik, sebuah instansi resmi yang ditunjuk oleh pemerintah untuk mengolah dan mengelola berbagai data, diantaranya data kependudukan, 
demografi, kependudukan, perekonomian dan lain sebagainya. Data pengangguran yang digunakan dalam penelitian ini adalah data pengangguran terbuka dengan pertimbangan bahwa pengangguran terbuka merupakan pengangguran yang benarbenar tidak bekerja. Data inflasi dan data produk domestik bruto pada penelitian ini menggunakan data inflasi dan data produk domestik bruto berdasarkan harga tetap dengan tujuan untuk mengetahui perkembangan inflasi dan produk domestik bruto di Indonesia. Data pengangguran, inflasi dan produk domestik bruto Indonesia tahun 2010-2019 dapat dilihat pada tabel 1 berikut.

Tabel 1. Pengangguran, inflasi dan produk domestik bruto Indonesia tahun 2010-2019

\begin{tabular}{|l|l|l|l|}
\hline Tahun & Pengangguran & Inflasi & PDB \\
\hline 2010 & $8.319 .779,00$ & 6,96 & $6.864 .133,10$ \\
\hline 2011 & $8.681 .392,00$ & 3,79 & $7.831 .726,00$ \\
\hline 2012 & $7.344 .866,00$ & 4,30 & $8.615 .704,50$ \\
\hline 2013 & $7.410 .931,00$ & 8,38 & $9.546 .134,00$ \\
\hline 2014 & $7.244 .905,00$ & 8,36 & $8.564 .866,60$ \\
\hline 2015 & $7.560 .822,00$ & 3,35 & $8.982 .517,10$ \\
\hline 2016 & $7.031 .775,00$ & 3,02 & $9.434 .613,40$ \\
\hline 2017 & $7.005 .262,00$ & 3,61 & $9.912 .703,60$ \\
\hline 2018 & $7.000 .691,00$ & 3,13 & $10.425 .316,30$ \\
\hline 2019 & $6.612 .738,69$ & 2,31 & $10.905 .652,13$ \\
\hline
\end{tabular}

Dari tabel 1 diatas dapat disimpulkan bahwa pengangguran Indonesia mengalami penurunan, angka inflasi naik turun, sedangkan produk domestik bruto mengalami kenaikan yang cukup siknifikan. Data pada tabel 1 dapat diperjelas sengan grafik seperti terlihat pada gambar 2 berikut.

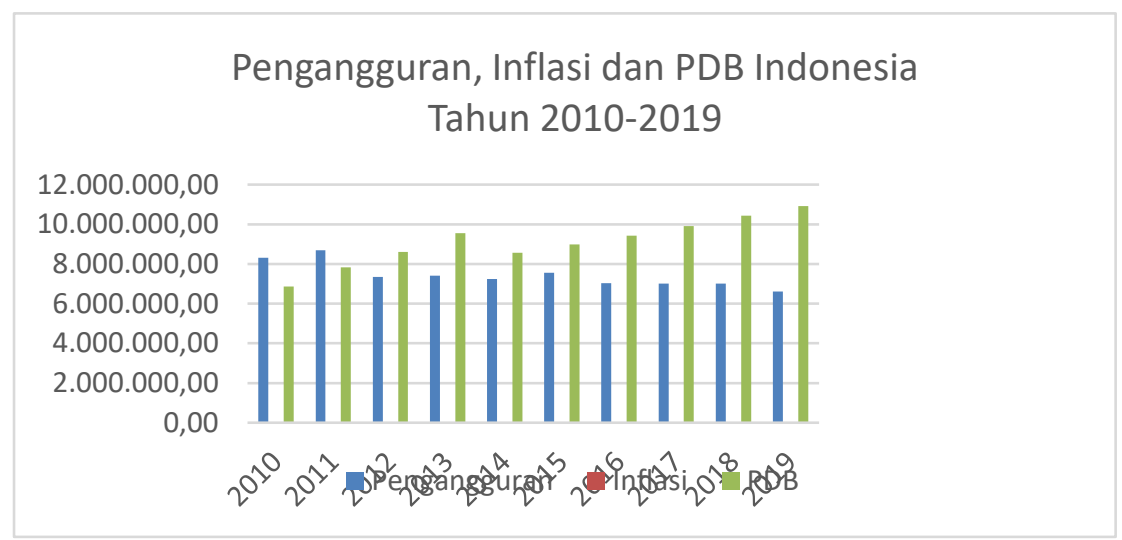

Gambar 2. Grafik Pengangguran, Inflasi dan PDB Indonesia Tahun 2010-2019 
Dari gambar 2 diat terlihat kenaikan dan penurunan data pengangguran, inflasi dan PDB Indonesia tahun 2010-2019.

\section{Uji Normalitas.}

Olah data dengan menggunakan SPSS 22 One Sample Kolmogorov Smirnov menghasilkan tabel berikut.

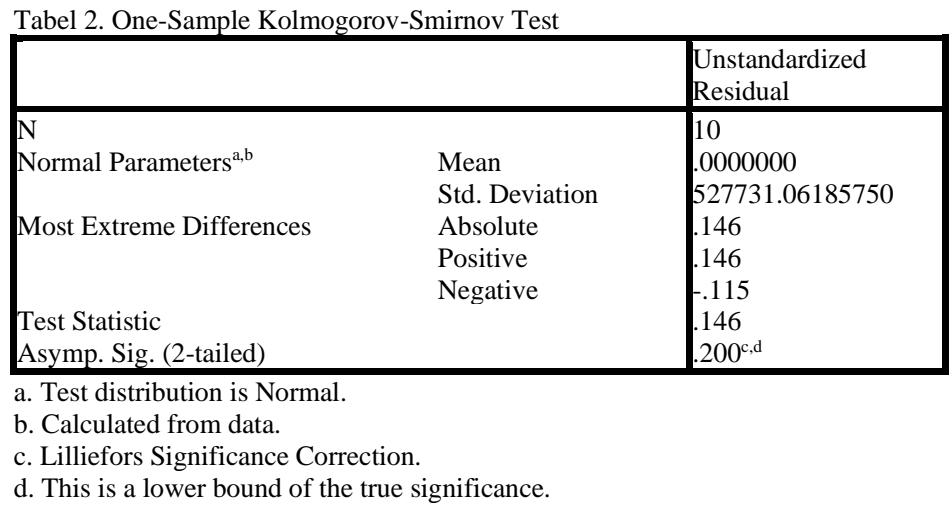

Dari Tabel 2 diperoleh angka Asymp. Sig. (2-tailed)sebesar 0.200 dimana angka tersebut lebih besar dari 0.05 sehingga dapat disimpulkan bahwa data berdistribusi normal.

Kurva Normal P-Plot of Regression Standardized Residual variabel dependen PDB terlihat pada gambar 4 berikut.

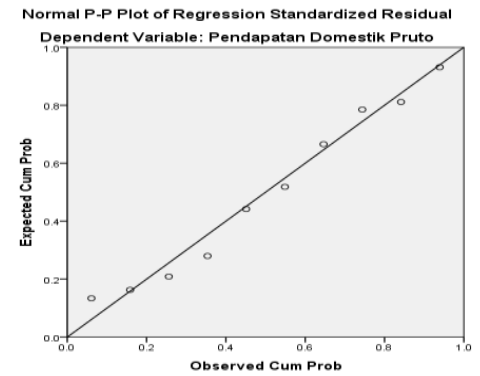

Gambar 3. Normal P-Plot of Regression Standardized Residual variabel dependen PDB Gambar 3 diatas menunjukkan bahwa titik-titik yang merupakan gambaran diagram pencar membentuk satu garis linier, sehingga dapat disimpulkan bahwa uji normalitas terpenuhi.

\section{Uji Multikolinieritas.}

Hasil olah data menggunakan SPSS.22 untuk uji ini dapat dilihat pada tabel berikut. 
Tabel 3. Coeficients Collinearrity Statistics

\begin{tabular}{|c|c|c|c|c|c|c|c|c|}
\hline \multicolumn{9}{|c|}{ Coefficients $^{\mathrm{a}}$} \\
\hline \multirow[b]{2}{*}{ Model } & & \multicolumn{2}{|c|}{ Unstandardized Coefficients } & \multirow{2}{*}{$\begin{array}{c}\text { Standardized } \\
\text { Coefficients } \\
\text { Beta }\end{array}$} & \multirow[b]{2}{*}{$t$} & \multirow[b]{2}{*}{ Sig. } & \multicolumn{2}{|c|}{ Collinearity Statistics } \\
\hline & & $B$ & Std. Error & & & & Tolerance & VIF \\
\hline \multirow[t]{3}{*}{1} & (Constant) & 21036872.29 & 2361514.539 & & 8.908 & .000 & & \\
\hline & Pengangguran & -1.526 & .329 & .800 & -4.640 & .002 & .917 & 1.090 \\
\hline & Inflasi & -127482.199 & 91089.465 & -241 & -1.400 & .204 & .917 & 1.090 \\
\hline
\end{tabular}

Dari tabel 3 diatas diperoleh nilai collinearity 0,917 dimana nilai tersebut lebih besar dari 0,1. VIF menunjukkan angka1.090 dimana nilai tersebut lebih kecil dari 10. Oleh karena itu dapat disimpulkan bahwa pada penelitian ini tidak terdapat multi kolinieritas

\section{Uji Autokorelasi}

Olah data uji autokorelasi menghasilkan tabel berikut.

Tabel 4. Uji Autokorelasi

\begin{tabular}{|l|r|r|r|r|r|}
\hline & & & & \multicolumn{1}{c|}{ Model Summary $^{\mathbf{b}}$} \\
Model & \multicolumn{1}{|c|}{$\mathrm{R}$} & R Square & Adjusted R Square & \multicolumn{1}{c|}{ Estimate } & Durbin-Watson \\
\hline 1 & $.900^{\mathrm{a}}$ & .809 & .755 & 598390.77806 & 2.926 \\
\hline
\end{tabular}

a. Predictors: (Constant), Inflasi, Pengangguran

b. Dependent Variable: Pendapatan Domestik Pruto

Tabel 4 diatas menunjukkan bahwa nilai durbin watson sebesar 2.926. Dari tabel durbin watson dengan $(\mathrm{k} ; \mathrm{N})=(2 ; 10)$ diperoleh nilai $\mathrm{dL}$ sebesar 0.6972 dan $\mathrm{dU}$ sebesar 1.6413. Nilai durbin watson sebesar 2.926 berada diatas dU yaitu 1.6413 sehingga penilitian ini tidak mengal;ami autokorelasi.

\section{Uji Heterokedastisitas}

Olah data uji heterokedestisitas dengan menggunakan SPSS.22 menghasilkan kurva scatterplots sebagai berikut. 


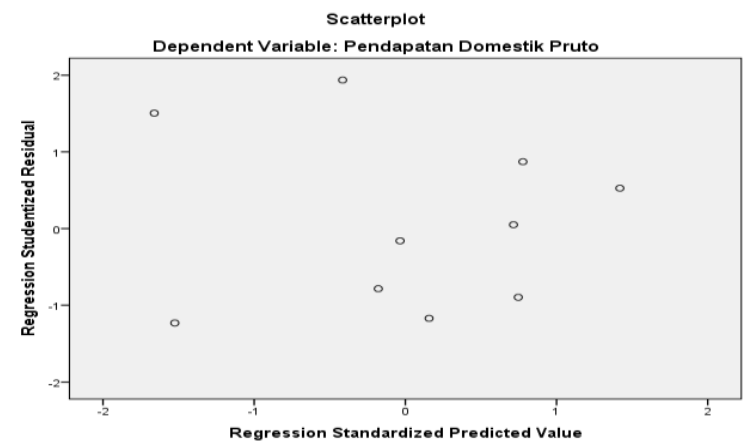

Gambar 4. Scatterplot Variabel Dependen PDB

Gambar 4 diatas menunjukkan bahwa titik-titik menyebar tidak membentuk pola tertentu sehingga dapat disimpulkan bahwa penelitian ini tidak mengalami heterokedestisitas, dan penelitian memebuhi persyaratan uji heterokedestisitas.

\section{Analisa Regresi Linier Sederhana (Uji t)}

Analisa ini bertujuan untuk mengetahui seberapa besar hubungan antara variabel bebas dengan terikat. Berikut ini adalah tabel hasil olah data untuk koefisien korelasi dengan menggunakan SPSS 22.

1. Pengaruh Pengangguran Terhadap Produk Domestik Bruto.

Tabel 5. Tabel Koefisien Korelasi Pengangguran Terhadap Produk Domestik Bruto.

Coefficients $^{\mathrm{a}}$

\begin{tabular}{|c|c|c|c|c|c|}
\hline \multirow[b]{2}{*}{ Model } & \multicolumn{2}{|c|}{ Unstandardized Coefficients } & \multirow{2}{*}{\begin{tabular}{|c|}
$\begin{array}{c}\text { Standardized } \\
\text { Coefficients }\end{array}$ \\
Beta \\
\end{tabular}} & \multirow[b]{2}{*}{$\mathrm{t}$} & \multirow[b]{2}{*}{ Sig. } \\
\hline & $\mathrm{B}$ & Std. Error & & & \\
\hline $\begin{array}{ll}1 & \text { (Constant) } \\
& \text { Pengangguran }\end{array}$ & $\begin{array}{l}21416759.612 \\
-1.659\end{array}$ & $\begin{array}{l}2482444.317 \\
.333\end{array}$ & -.869 & $\begin{array}{l}8.627 \\
-4.974\end{array}$ & .000 \\
\hline
\end{tabular}

a. Dependent Variable: Pendapatan Domestik Pruto

Dari tabel 5 diatas diketahui bahwa nilai t hitung sebesar -4.974 dimana nilai tersebut lebih besar dari nilai t tabel dengan $0.025 ; 8$ yaitu 2.300 sehingga dapat disimpulkan bahwa H1a diterim, H0a ditolak. Hal ini dapat diartikan bahwa terdapat pengaruh signifikan pengangguran terhadap produk domestik bruto.

2. Pengeruh Inflasi Terhadap Produk Domestik Bruto

Tabel 6. Tabel Koefisien Korelasi Inflasi Terhadap Produk Domestik Bruto Coefficients ${ }^{\mathrm{a}}$ 


\begin{tabular}{|c|c|c|c|c|c|}
\hline \multirow[b]{2}{*}{ Model } & \multicolumn{2}{|c|}{ Unstandardized Coefficients } & \multirow{2}{*}{$\begin{array}{c}\begin{array}{c}\text { Standardized } \\
\text { Coefficients }\end{array} \\
\text { Beta }\end{array}$} & \multirow[b]{2}{*}{$\mathrm{t}$} & \multirow[b]{2}{*}{ Sig. } \\
\hline & $\mathrm{B}$ & Std. Error & & & \\
\hline $\begin{array}{l}1 \text { (Constant) } \\
\text { Inflasi }\end{array}$ & $\begin{array}{l}10283528.953 \\
-248928.676\end{array}$ & $\begin{array}{l}855978.416 \\
164758.235\end{array}$ & 471 & $\begin{array}{c}12.014 \\
1511\end{array}$ & $\begin{array}{l}.000 \\
160\end{array}$ \\
\hline
\end{tabular}

a. Dependent Variable: Pendapatan Domestik Pruto

Dari tabel 6 diatas diketahui bahwa nilai t hitung sebesar -1.511 dimana nilai tersebut lebih kecil dari nilai t tabel dengan $0.025 ; 8$ yaitu 2.300 sehingga dapat disimpulkan bahwa H1b ditolak, H0b diterima. Hal ini dapat diartikan bahwa tidak terdapat pengaruh inflasi terhadap produk domestik bruto.

\section{Analisis Regresi Berganda (Uji F)}

Analisa ini bertujuan untuk mengetahui seberapa besar hubungan antara beberapa variabel bebas secara bersama-sama terhadap terikat. Berikut ini adalah tabel hasil olah data untuk koefisien korelasi dengan menggunakan SPSS 22.

Tabel 7. Tabel Analisis Berganda

\section{ANOVA $^{\mathrm{a}}$}

\begin{tabular}{|c|c|c|l|l|l|}
\hline Model & \multicolumn{1}{c|}{ Sum of Squares } & df & Mean Square & F & \multicolumn{1}{c|}{ Sig. } \\
\hline 1 Regression & 10623467912977.273 & 2 & 5311733956488 & 14.834 & $.003^{\mathrm{b}}$ \\
Residual & 2506500662843.221 & 7 & $\begin{array}{l}658071523263 . \\
317\end{array}$ & & \\
Total & 13129968575820.494 & 9 & & & \\
\hline
\end{tabular}

a. Dependent Variable: Pendapatan Domestik Pruto

b. Predictors: (Constant), Inflasi, Pengangguran

Dari Tabel 7 diatas diperoleh bahwa nilai Fhitung adalah 14.834. Nilai F tabel pada signifikansi 5\% dengan df (3;7) sebesar 4,35. Karena F hitung (14.834) lebih besat dari nilai F tabel (4.35), maka dapat disimpulkan bahwa Pengangguran dan Inflasi secara bersama-sama berpengaruh signifikan terhadap pendapatan domestik bruto.

Hasil analisis linier berganda pada penelitian ini diperoleh dari hasil olah data menggunakan SPSS.22 adalah sebagai berikut.

Tabel 8. Hasil Analisis Regresi Linear Berganda Coefficients $^{\mathrm{a}}$

\begin{tabular}{|c|c|c|c|c|c|}
\hline & Unstandardized & Coefficients & $\begin{array}{l}\text { Standardized } \\
\text { Coefficients }\end{array}$ & & \\
\hline Model & $\mathrm{B}$ & Std. Error & Beta & $\mathrm{t}$ & Sig. \\
\hline 1 (Constant) & 21036872.292 & 2361514.539 & & 8.908 & .000 \\
\hline
\end{tabular}




\begin{tabular}{|l|l|l|l|l|l|}
\hline Pengangguran & -1.526 & .329 & -.800 & -4.640 & .002 \\
Inflasi & -127482.199 & 91089.465 & -.241 & -1.400 & .204 \\
\hline
\end{tabular}

a. Dependent Variable: Pendapatan Domestik Pruto

Dari tabel 8 diatas dapat disimpulkan bahwa persamaan regresi pada penelitian ini adalah sebagai berikut:

$$
\mathrm{Y}=21036872.292-1.526 \mathrm{X} 1-127482.199 \mathrm{X} 2+\mathrm{e}
$$

Dimana :

$$
\begin{aligned}
& \mathrm{Y}=\text { Pendapatan Domestik Bruto } \\
& \mathrm{X} 1 \text { = Pengangguran } \\
& \mathrm{X} 2 \text { = Inflasi }
\end{aligned}
$$

Persamaan regresi di atas dapat dartikan sebagai berikut:

- Konstanta sebesar 21036872.292, artinya jika Pengangguran (X1) dan Inflasi (X2) nilainya adalah 0, maka Produk Domestik Bruto (Y') nilainya adalah Rp21036872.292,00

- Koefisien regresi variabel Pengangguran (X1) sebesar - 1.526; artinya jika variabel independen lain nilainya tetap dan Pengangguran mengalami kenaikan 1\%, maka Produk Domestik Bruto (Y') akan mengalami penurunan sebesar Rp.1.526 dan sebaliknya. Koefisien bernilai negatif artinya terjadi hubungan negatif antara Pengangguran dengan Produk Domestik Bruto, semakin naik Pengangguran maka Produk Domestik Bruto semakin turun.

- Koefisien regresi variabel Inflasi (X2) sebesar -127482.199; artinya jika variabel independen lain nilainya tetap dan Inflasi mengalami kenaikan 1\%, maka Produk Domestik Bruto (Y') akan mengalami penurunan sebesar Rp. 127482.199. Koefisien bernilai negatif artinya terjadi hubungan berbanding terbalik antara Inflasi dengan Produk Domestik Bruto, semakin naik Inflasi maka semakin turun Produk Domestik Bruto.

\title{
Analisis Korelasi Berganda.
}

Olah data dengan SPSS.22 menghasilkan output moddel summary dan sebagai berikut:

Tabel 8. Hasil Analisis Korelasi Berganda

\author{
Model Summary
}




\begin{tabular}{|l|r|r|r|c|}
\hline Model & \multicolumn{1}{|c|}{$\mathrm{R}$} & R Square & \multicolumn{1}{c|}{$\begin{array}{c}\text { Adjusted R } \\
\text { Square }\end{array}$} & $\begin{array}{l}\text { Std. Error of the } \\
\text { Estimate }\end{array}$ \\
\hline 1 & $.900^{\mathrm{a}}$ & .809 & .755 & 598390.77806 \\
\hline
\end{tabular}

a. Predictors: (Constant), Inflasi, Pengangguran

b. Dependent Variable: Pendapatan Domestik Pruto

Dari tabel 8 diatas diperoleh bahwa nilai koefisien korelasi (R) sebesar 0.900 . Menurut Sugiyono (2014) kekuatan pengaruh antara variabel X dan Y adalah sebagai berikut:

Nilai $R=0$

0,25

$0,25 \operatorname{sd} 0,50$

0,50 sd 0,75

$0,75 \operatorname{sd} 0,99$ artinya tidak ada korelasi antara dua variabel $0,00 \mathrm{sd}$ artinya korelasi sangat lemah artinya korelasi cukup artinya korelasi kuat artinya korelasi sangat kuat

Hasil uji regresi linear dengan SPSS. 22 didapat nilai R koefisien korelasi sebesar 0,900, sehingga dapat diartikan bahwa pengaruh variabel Pengangguran (X1) dan Inflasi (X2) terhadap Produk Domestik Bruto sangat kuat. Nilai Rsquare 0,809 artinya bahwa Pengangguran (X1) dan Inflasi (X2) memiliki kontribusi mempengaruhi variabel Produk Domestik Bruto (Y) sebesar 80.9\% sisanya dipengaruhi oleh faktor faktor lain Yng tidak dibahas pada penelitian ini.

\section{SIMPULAN}

\section{Kesimpulan}

Dari paparan diatas dapat disimpulkan bahwa nilai t hitung pada pengaruh pengangguran terhadap produk domestik bruto sebesar $-4.974>2.300$ yang merupakan nilai nilai t tabel dengan 0.025;8 sehingga dapat diartikan bahwa terdapat pengaruh signifikan pengangguran terhadap produk domestik bruto. Nilai t hitunginflasi terhadap produk domestik bruto sebesar $-1.511<2.300$ sehingga dapat diartikan bahwa tidak terdapat pengaruh inflasi terhadap produk domestik bruto. Nilai Fhitung adalah $14.834>4.35$ yang merupakan nilai F tabel pada signifikansi 5\% dengan df $(3 ; 7)$ maka dapat dikatakan bahwa Pengangguran dan Inflasi secara bersama-sama berpengaruh signifikan terhadap pendapatan domestik bruto. Persamaan regresi pada penelitian ini adalah $\mathrm{Y}=21036872.292-1.526 \mathrm{X} 1$ - 127482.199X2 + e. Nilai R koefisien korelasi sebesar 0,900, maka dapat diartikan 
bahwa pengaruh variabel Pengangguran (X1) dan Inflasi (X2) terhadap Produk Domestik Bruto sangat kuat. Nilai R square 0,809 artinya bahwa Pengangguran (X1) dan Inflasi (X2) memiliki kontribusi mempengaruhi variabel Produk Domestik Bruto (Y) sebesar 80.9\% sisanya dipengaruhi oleh faktor faktor lain Yng tidak dibahas pada penelitian ini.

\section{Saran}

Dari kesimpulan diatas dimana pengangguran memiliki pengaruh sangat kuat terhadap produk domestik bruto. Untuk itu sudah benar sekali kebijakan yang diambil Presiden Jokowi pada periode ini, yaitu mengedepankan peningkatan kualitas sumber daya manusia.. Dengan peningkatan kualitas sumber daya manusia ini diharapkan dapat menurunkan pengangguran, misalnya mendidik SDM untuk menciptakan lapangan kerja sehingga dapat meningkatkan Pendapatan Domestik Bruto. Inflasi di Indonesia tidak berpengaruh terhadap Produk Domestik Bruto mengingat inflasi yang terjadi masih tergolong inflasi ringan ( $<10 \%$ setahun). Inflasi pada tingkat ini justru mendorong sektor usaha. Untuk itu disarankan agar Pemerintah Indonesia tetap mempertahankan inflasi jangan sampai inflasi $>10 \%$ setahun, diantaranya dengan menjaga keseimbangan jumlah uang yang beredar dengan besarnya transaksi keuangan, menjaga keseimbangan barang dan jasa yang dibutuhkan masyarakat dengan barang dan jasa yang tersedia di masyarakat.

\section{DAFTAR RUJUKAN}

Sugiyono, 2014. Metode Penelitian Pendidikan Pendekatanan Kuantitatif, Kualitatif, dan R\&D. Bandung: Alfabeta.

Sukirno, Sadono. 2011. Makro Ekonomi Teori Pengantar Edisi Ketiga. Rajawali Pers, Jakarta

www.bps.go.id .2019 